\title{
Need For Changing The Civil Services System In India
}

\section{N.M.Kanakane}

\begin{abstract}
The authority of Parliament or the State Legislature should be and is preeminent, however it would be baffling the point of majority rule government to let the impact of political or gatherings of people working in the lawmaking body or outside to influence enlistment or advancement in the administrations. In liberated India, it was the expectation that legislators who were brought into the world in upset and common noncompliance ought to before long figure out how to become overseers. However, this interaction has been slow. All things being equal, at the opposite end, overseers are maybe having a tendency to become legislators, which is terrible. What is fundamental at the top is the ability to decide upon important exhortation and to choose immediately and appropriately in leader matters. To choose in issues chief, rapidly and effectively, is an endowment of the divine beings. What's more, this is it that makes a decent chairman. India is a protected vote based system and its working chiefly relies on four columns Legislature, Executive, Judiciary, and Free Press. Every last one of these has been alloted its part in our majority rule arrangement. Initial three of these are related with the administration of the State. Viable and productive foundations structure the foundation of a fruitful turn of events and administration measure. In this specific situation, the principal architects had the prescience to make the essential institutional structure for administration which has brought us hence far. One of the essential components of Indian administration engineering is the idea of an unbiased, fair, proficient and daring common help which is the center of the Executive, be it the All India Services or the other Civil Services. They structure the extremely durable construction and spine of Indian Administration System. Much had been fundamentally examined and expounded on common administrations' accomplishments as far as assumptions at the hour of birth of Indian Republic and its achievements up until this point. All in all, in this paper, I need to think whether this structure is satisfactory for quite a long time to come; regardless of whether past methods of working will address the requests of things to come in quick evolving world; whether abilities and capacities that were applicable in the past have outlasted their utility and there is a need to foster new ones? By responding to these inquiries,
\end{abstract}


I would examine that whether there are changes in the job of Indian Civil Services and on the off chance that it needs reorientation in such manner.

\section{What is Civil Service?}

Civil Service means a group of people who share in the exercise of the sovereign power of the state by discharging the various functions of the executive branch of government other than military responsibilities as a life career and paid from government treasury. Indian Civil Service is a legacy of the British administration in India. Started by Warren Hastings and later modifies by Sardar Vallabhai Patel, Civil Service is the steel frame of the political system.

\section{Why Civil Services?}

1) Power and Prestige

2) Security of Service

3) Challenging Profession

4) Variety of Responsibilities

5) Opportunity to serve many

6) Opportunity to make remarkable contributors

7) Opportunity for higher placements

8) Opportunity for higher studies

9) Selection on Merit

10) Assured Promotions

11) Beneficial to the individual, family, locality and state

12) Attractive pay and perks.

\section{Civil Services and Governance in Independent India:}

The common assistance framework is the foundation of the regulatory framework which goes about as most significant instrument for administration of our country. In post-autonomous India common assistance was revamped. There are three levels of organization Union/Central Government, State Government, and Local Government. At the focal level, the common administrations incorporate the All India Services, in particular the Indian Administrative Service (IAS). Indian Foreign Service (IFS), Indian Forest Service (IFS), and Indian Police Service (IPS). Aside from these there are different other Central Services like 
the Indian Income Tax Service, Indian Railways Service, and so on at focal level. The State Governments have there own arrangement of administrations - State Civil Service. Over the period the job of common administrations has changed relying upon the plan of the administration of that specific period. During British period, authorization of peace and lawfulness and assortment of income was the principle worry of government workers. In post freedom India, when the Government has gained the job of Welfare State, common administrations go about as a significant apparatus for executing public and state arrangements of government assistance and arranged turn of events. The Indian common administrations, with its public person, have been a solid restricting power to the Union of States. The foundation of common assistance has delivered administration to the generally speaking financial advancement of the country. It has been at the front line of the advancement cycle directly from the 'instructing statures system' to the 'progression and liberation period'. It has gone about as a power of solidarity among variety. It has not just assumed an essential part in planning and initiating approaches, it has likewise guaranteed fundamental help conveyance at the grass root level to the peripheral segment of our general public.

Since common administrations are considered as the main component of Indian managerial framework that has the obligation to satisfy the improvement destinations of the government assistance state, in this way, any disappointment or inadequacies in satisfaction of these goals are credited to the disappointment of common administrations. It is said that India's enormous organization is kept up with at colossal expense by the country's citizen whose normal pay is among the least on the planet. The public insight about the individuals from the common assistance, who work at bleeding edge, higher coordination and strategy making levels, is that they are 'oppressive low-entertainers' going a profoundly swollen administration, which is, regularly, seen to be bad and wasteful in administering the country. A portion of the analysis of Indian common administrations is:

- Lack of polished methodology and helpless limit building

- Alienation from general society and absence of comprehension of what individuals need

- Inefficient motivator frameworks that don't see the value in upstanding and extraordinary

- civil workers yet reward the bad and the uncouth

- Outmoded decides and techniques that limit the government employee from performing viably

- Lack of execution culture and spotlight on yields and results - 
- inappropriate execution examination

- Systemic irregularities in advancement and empanelment

- Lack of sufficient straightforwardness and responsibility strategies - there is likewise no wellbeing for informants

- Arbitrary and eccentric exchanges - frailty in residencies obstructs organization

- Political obstruction and regulatory quiet submission

- A continuous disintegration openly administration esteems, morals and assurance

Along these lines, based on experience up until now and some different improvements of the current time like globalization, alliance nature of country, and so on, it is all around perceived that transforming the common help isn't just fundamental yet additionally inescapable.

\section{'Good Governance' and Civil Service Reform in Present Context}

As of late, a few new wonders have arisen in the field of administration which have expansive outcomes. For 'Great Governance' which is one of the main objectives of the advanced government assistance State, common administrations must be receptive to these changes. Be that as it may, for this reaction, changes and reorientation of common administrations are required in light of the fact that with its current mentality and preparing common administrations won't convey great administration in the current complex world. A well-working common assistance assists with encouraging great policymaking, successful help conveyance, responsibility and obligation in using public assets which are the attributes of good administration. 'Great Governance' is being utilized as a comprehensive structure for regulatory and common assistance change, yet as a connection between Civil Service Reform and a sweeping structure for settling on approach choices compelling inside reasonable frameworks of responsibility and resident interest. Managerial change centers around legitimizing constructions and tasks of government hardware. Administration change will in general zero in on working with the viable working of and collaborations between the State, the market and the common society. It alludes to the improvement of legitimate, institutional and strategy systems to establish appropriate dynamic and execution conditions for monetary development and circulation. It envelops participatory frameworks for components of common society to turn out to be effectively engaged with plan of approaches and programs and their execution. It likewise incorporates powerful and straightforward frameworks and cycles for responsibility in government exercises. Common help change can't be found in segregation and it must be attempted alongside regulatory and administration changes for 
compelling outcomes. Albeit complete change that includes administration, the common help, managerial practices, and common society is great, it requires supported responsibility from political and authoritative pioneers. It is additionally too complex to even consider carrying out at the same time. Scarcely any nations have embraced thorough changes and there are blended outcomes. The test lies in discovering linkages among the administration, common help and common society parts, figuring out which require need consideration. Be that as it may, without going into this need banter, this paper would examine a portion of the significant components influencing administration in present time and a need to get ready common administrations to confront the circumstance emerging out of these variables. Most significant improvement of our occasions which has generously changed the idea of administration is - Globalization. Lately globalization has saturated each alcove and corner of our nation and its kin. Reason being dynamic exchange and trade across board; administration of which goes under the domain of common administrations; consequently requiring more prominent blending of common administrations with the marvels globalization. Henceforth initially let us attempt to comprehend this marvels and the requirement for this blending, concealed in spread and degree of globalization in our country.

\section{Role of Civil Services in Governance}

A Civil Service in any country have the following roles in general

\section{Basis of Government}

Civil services form the basis of the governments. No government can exist without administrative machinery. All nations, irrespective of their system of government, require some sort of administrative machinery for implementing policies. E.g. Democracies like India and Communist countries like China have their own forms of civil services.

\section{Policy Making \& Implementation}

The job of Civil Servants across the spaces of strategy making and strategy execution is basic to the improvement interaction. They help with recognizing significant arrangement regions, for example, planning significant strategy recommendations, examining different other options and answers for cultural issues requiring pressing consideration, separating the significant approaches into sub-strategies, deciding project of activity and proposing change in the current approach based on its experience on the execution front.

- They take part in assortment of important information and data to distinguish center issues. The kind of data required, the degree of substance in the data so gathered and absorption of 
the data is the errand of the Civil Servants. They then, at that point, help the public authority as far as giving pertinent information to proving strategy proposition.

- Owing to their huge authoritative skill and capacity of the common administrations, they are conscious of different issues and issues confronting the country. Their insight and experience so procured is then put to use by expecting the job of the 'think-tank' about the public authority. The Civil Servants help the political leader in distinguishing strategy issues by recommending the idea of issues and the requirement for taking them up for thought at more significant levels.

- The common assistance connects with itself in inspecting the issue taken up for strategy plan, it outlines and rethinks strategy recommendations keeping in see its feasibility, future possibilities, assets accessible, worthiness, and so forth It is likewise the obligation of the common administrations to examine strategy proposition corresponding to the arrangements of the Constitution, the laws outlined by the Parliament, and other existing principles and guidelines. In this manner the common administrations help in outlining sound and powerful approaches.

- Civil workers are liable for executing the laws and approaches of government. Via doing laws, it controls the conduct of individuals in the public arena. The standards and destinations of government might be exceptionally well known, the designs for public advancement might be incredibly reformist and the assets of the nation might be bountiful, however without common administrations, very little can be accomplished. A productive common assistance can keep away from squander, right mistakes, limit the results of inadequacy or flippancy while carrying out laws and public approaches.

\section{Providing Services to People}

Policy implementation run by government employees gives countless administrations to individuals, for example,

- Protective Functions:

- They secure the life and property of individuals by keeping law and control. The endurance and progress of individuals rely upon the appropriate requirement of laws against criminals. For example Forestalling and controlling coordinated wrongdoing in any area.

- In late occasions, insurance of the climate is added to the defensive elements of the public authority. Because of quick industrialisation, there is the issue of natural contamination which undermines our lives. Presently practically every one of the administrations are putting forth 
attempts at the improvement of ecological quality. For example Guaranteeing that enterprises maintain the air, water, strong waste and different standards under the different demonstrations established in the country.

- Management of public undertakings: Civil workers are additionally overseeing public ventures and public utilities in light of a legitimate concern for financial equity. Public utilities are either freely possessed or rigorously controlled in many nations. Government additionally forces powers over private monetary and business exercises in the public interest. For example Previous IAS Officer Dr. P. D. Shenoy upgraded the presentation of the Karnataka State Road Transport Corporation (KSRTC), which had made misfortunes constantly for a very long time until he turned into its Managing Director and in that year the organization made benefit.

- Welfare benefits: The government assistance administrations accommodated individuals incorporate federal retirement aide, advanced age annuities, government assistance of the more vulnerable areas, neediness easing and so forth For example Different endeavors by government workers are being valued in the administration of COVID-19 pandemic in India.

\section{Evolution of Civil Services in India}

\section{Common Services in Ancient India}

The Indian common assistance framework is one of the most seasoned regulatory frameworks on the planet. It had its starting point in the Mauryan time frame during antiquated India. Kautilya's Arthashastra sets out the standards of choice and advancement of the government employees, the states of dedication for arrangement to the common assistance, the strategies for their exhibition assessment and the implicit rules to be trailed by them.

\section{Common Services in Medieval India}

In archaic India, the Mughals set up their own common help frameworks which focused on the administration of land income, organization of government processing plants and foundation of the patrimonial state. During this period, Akbar established and supported the common help. During his period, he started land changes (1457 AD), and set up the land income framework which later turned into a significant constituent of the Indian tax assessment framework. His common assistance had government assistance and an administrative direction.

\section{Common Services in Colonial Era}


The East India Company had a common assistance explicitly liable for completing business capacities. They were segregated from the everyday citizens. At first it was important for the police state with its fundamental assignment being that of doing peace and lawfulness capacities. The workplace of the District Collector was made without precedent for 1771 by Lord Warren Hastings. Notwithstanding, it was Lord Cornwallis, who is viewed as the principal architect of current Indian Civil Services. He made police administration, legal assistance and income administrations, defined the set of principles for government workers and set out the technique for their advancement. Indians were banished from high posts from earliest reference point.

In 1800 Lord Wellesley established the Fort William College to prepare government workers. Notwithstanding, from 1806, the Fort William College was supplanted by Hailey Bury College in London to prepare government workers. The 1813 Charter Act the workplace of government employees as the common help with a yearly compensation of 500 lakes. Ruler William Bentinck reestablished, and resuscitated authoritative forces of locale gatherer which was stripped by Lord Cornwallis. Sanction demonstration of 1853 finished the organizations' support and accommodated open rivalry in enrollment. Albeit hypothetically it was made open, yet the applicable arrangements were never truly carried out until 1858.

The British government set up the Indian common assistance in 1911. At first the enrollment to the Indian common help was restricted distinctly to the British. Be that as it may, because of tensions and requests raised by the Indian National Congress in 1921, Indians were permitted to take the assessment. In 1935 the British government chose to build up interval rule in the different territories of India, which brought about a mass migration of the British subjects as government workers and therefore, the quantity of Indian subjects in the Indian common help expanded enormously. However at first the British government set up just the Indian common assistance, later on they added a legal common help and focal common administrations. Throughout time the legal common assistance was gotten rid of and there stayed on the scene just the excess two administrations, to be specific, the Indian Civil Service and the focal common administrations.

\section{Civil Services Reforms in India}

A number of Committees and Commissions were set up to make recommendations on various aspects of civil services. These recommendations are included in the

- Report on Public Administration by A.D. Gorwala, 1951; 
- Report on the Public Services (Qualifications for Recruitment) Committee, 1956 - also known as Dr. A. Ramaswami Mudaliar Committee Report;

- Report on Indian and State Administrative Services and Problems of District Administration by V.T. Krishnamachari, 1962;

- Report on Personnel Administration by the Administrative Reforms Commission I, 1969;

- Report of the Committee on Recruitment Policy and Selection Methods, 1976 - also known as the D.S. Kothari Committee Report;

- Report of the Committee to Review the Scheme of the Civil Services Examination, 1989 also known as the Satish Chandra Committee Report;

- Report of the Civil Services Examination Review Committee, 2001, also known as Professor

Yoginder K. Alagh Committee Report;

- Report of the Committee on Civil Service Reforms also known as the Hota Committee Report, 2004. Report on Refurbishing of Personnel Administration \& Scaling New Heights by the Administrative Reforms Commission II, 2008.

\section{Civil Service Reforms and Good Governance}

A well-functioning civil service helps to foster good policymaking, effective service delivery, accountability and responsibility in utilizing public resources which are the characteristics of good governance. "Good Governance" is being used as an all-inclusive framework not only for administrative and civil service reform, but as a link between Civil Service Reform and an all-embracing framework for making policy decisions effective within viable systems of accountability and citizen participation. Administrative reform focuses on rationalizing structures of government. Governance reform tends to refer to the improvement of legal and policy frameworks to create proper decision making environment; participatory systems for elements of civil society to become actively involved in policy and programme formulation and their implementation; and an effective and transparent system and process for control and accountability in government activities. Civil Services reform cannot be seen in isolation and it has to be undertaken along with administrative reforms for effective results. Although comprehensive reform that involves governance, the civil service, and civil society is ideal, it requires sustained commitment from political and administrative leaders. It is also too complex to implement all at once. Few countries have undertaken comprehensive reforms 
and there are mixed results. The challenge lies in finding and linkages among the governance, civil service and civil society components, determining which require priority attention.

\section{Civil Service Reforms and Socio-Economic Development}

Civil Service Reform aims at strengthening administrative capacity to perform core government functions. These reforms raise the quality of services to the citizens that are essential to the promotion of sustainable economic and social development. CSR can contribute to macroeconomic stabilization by restoring budgetary stability, strengthening revenue collection, managing aid effectively, and improving development performance through proper implementation of investment frameworks and the management of public expenditure plans and programmes. The reform can contribute to the design and implementation of an equitable programme of social development. Enhancing the capacity of civil servants and improving their morale are critical to all these functions.

\section{References:}

1. Beteille Andre. Antinomies of Society: Essays on Ideologies and Institutions.Oxford

2. University Press. New Delhi. 2000.

3. Das, S.K. Civil Service Reform and Structural Adjustment. Oxford University Press. 1998.

4. Farazmand Ali. Administrative Reform in Developing Nations. Praeger Publishers. 2001.

5. Government of India. Hota Committee Report on Civil Service Reforms. New Delhi. 2004.

6. Mamadou Dia. A Governance Approach to Civil Service Reform in Sub-Saharan Africa:

7. World Bank Technical Paper. World Bank. 1993.

8. Civil Services rationalization in India: World Bank, 2001.

9. Andre Betellie: Rule of law -'Experience of Governance: A sociological Overview'R.K.Dar (ed): Governance \& the IAS, 1999.

10. Committee on Civil Service Reforms: P.C. Hota Committee, July 2004. 